\title{
VILNIUS INTELLECTUALS AND THE EARLY 19TH-CENTURY CONCEPT OF LITHUANIA: THE SOCIETY OF SCOUNDRELS (TOWARZYSTWO SZUBRAWCÓW) AND LOCAL SOCIETY
}

\author{
Sayaka Kaji
}

\begin{abstract}
This article reconsiders intellectuals around Vilnius University and their relationships with local society and common people in the lands of the former Grand Duchy of Lithuania in the early 19th century. It focuses on the Society of Scoundrels (Towarzystwo Szubrawców) and its publication 'Street News' (Wiadomości Brukowe, 1816-22), a satirical journal criticising various social pathologies. Based on analyses of articles in 'Street News', it considers two issues: intellectuals' opinions about the nation (naród in Polish) and the class system, and their attitude towards the history and folk languages of Lithuania.
\end{abstract}

The members of the Society of Scoundrels considered that the nation should be composed not only of nobles but also of other classes. They thought of integrating the non-ruling classes into the national community through the abolition of serfdom and the spread of education. As their regulations, the Code of the Scoundrels, show, the members had an interest in Lithuanian mythology and history. Some articles described ancient Lithuanian society as democratic, in order to criticise contemporary society. During the latter half of its activities, however, the interest in Lithuanian history was reduced and even ridiculed. The use of Lithuanian as a written language was ridiculed more heavily than the interest in Lithuanian history. There was a gap between the interest in history, which was the past of the elites, and the interest in the language, which was not used by most of them. Thus, this Lithuanian nation would have been a community united by the Polish language. But if one considers that some members promoted the use of Lithuanian as a literary and educational language for Lithuanian-speaking people, it could have been multilingual with Polish high culture. In any case, it differs from the concept of the class-defined nation of the early modern 
age, and from the concept of a linguistically homogeneous nation consisting of all classes in the late 19 th century. ${ }^{1}$

Introduction From 1816 to 1822, 'Street News' (Wiadomości Brukowe) was published in Vilnius (Wilno/Vilna) by the Society of Scoundrels (Towarzystwo Szubrawców, hereafter 'the Scoundrels'). This publication provoked a public response on account of its sharp satires. Leading intellectuals of that time, such as professors at Vilnius University, joined the society, and it exercised an influence on their contemporaries. The western gubernias, mainly present-day Lithuania, Belarus, and part of Ukraine, were incorporated into the Russian Empire because of the partitions of the Polish-Lithuanian Commonwealth. Many nobles and intellectual elites of these gubernias were Polonised, and they differed from the common people linguistically, culturally, and in many cases religiously. In the early 19th century in this region, there was a growing interest in folk languages and culture. This article studies the Scoundrels as an example of intellectuals of Polish culture who were interested in regional society. Then, it tries to reconsider the relationships of these intellectuals with the local society and common people in the lands of the former Grand Duchy of Lithuania (i.e. present-day Lithuania and Belarus). These relationships have not been studied at length, because of the division of the history of this region into individual national histories.

The polonised upper classes and the high culture of the Polish language have often been regarded as belonging to a different nation; therefore, these have been marginalised in historical research. However, since the end of the 20th century, there has been an increase in historical works which focus on the polonised upper classes in the lands of the former Grand Duchy of Lithuania and the Commonwealth after the partitions. ${ }^{2}$ In recent years, some historians in

${ }^{1}$ This article is based on the following article published in Japanese by the same author, with some modifications and supplements: S. Kaji, 'Intellectuals in Early 19th-Century Vilnius and "Lithuania": Towarzystwo Szubrawców (the Society of Scoundrels) and Local Society', The Shirin or the Journal of History, 91-5 (no. 471) (2008).

${ }^{2}$ For example: J. Bardach, O dawnej i niedawnej Litwie (Poznań, 1988); D. Beauvois, Szkolnictwo polskie na ziemiach litewsko-ruskich 1803-1832, 2 vol. (Lublin, 1991) (the original: Lumières et société en Europe de l'Est: L'Université de Vilna et les écoles polonaises de l'Empire Russe (1803-1832), 2 vol. [Lille, 1977]); idem., Wilno: Polska stolica kulturalna zaboru rosyjskiego 1803-1832 (Wrocław, 2010); T. Snyder, The Reconstruction of Nations: Poland, Ukraine, Lithuania, Belarus, 1569-1999 (New Haven, 2003). 
Lithuania and Belarus have treated society in the first half of the 19th century as a multilingual society, in which many cultural activists were multilingual, and culture was fostered by speakers of various elitist (e.g. Polish and Russian) and folk languages. ${ }^{3}$ However, these historians have described it in the framework of national history; therefore, they have given priority to their own national language, and have limited their descriptions to the present territories of their states. Polish historiography has traditionally performed literary research on Polish culture and language in all the lands of the former Commonwealth. In recent years, several historians have paid attention to multilingualism in the culture and literature of the first half of the 19th century. ${ }^{4}$ However, these works have mainly concentrated on the literary aspect. Thus far, the historiography often lacks the perspective that questions the relations between classes using different languages (rather than between nations) in the era prior to nationalism.

It is necessary to mention the historiography of 'Street News' and the Scoundrels here. In the 19th century, from the romanticists' viewpoint, the Scoundrels were criticised for their lack of understanding of independence movements and romanticism; their good relations with the Russian government were also disapproved of. Chmielowski made a positivistic evaluation of the Scoundrels, especially their progressivity in social criticism and the pioneering spirit of publication and discourse. ${ }^{5}$ Subsequently, Ottman, Hordyński and Bieliński focused on revealing the process of the founding of 'Street News' and the Scoundrels, and studied their organisational structures and members. ${ }^{6}$ After the Second World War, Skwarczyński

${ }^{3}$ E. Aleksandravičius, A. Kulakauskas, Caru valdžioje: XIX amžiaus Lietuva (Vilnius, 1996); Ia.K. Novik, G.S. Martsul' (eds.), Gistoria Belarusi u dzvnikh chastkakh, ch. 1 (Minsk, 2000); Z. Szybieka, Historia Białorusi 1795-2000 (Lublin, 2002); J. Girdzijauskas et al., Lietuviu literatūros istorija: XIX amžius (Vilnius, 2001). Also see: H. Wisner, Litwa: Dzieje państwa i narodu (Warsaw, 1999).

${ }^{4}$ M. Litwinowicz-Droździel, O starożytnościach litewskich: Mitologizacja historii w XIX-wiecznym piśmiennictwie byłego Wielkiego Księstwa Litewskiego (Kraków, 2008); P. Bukowiec, Dwujęzyczne początki nowoczesnej literatury litewskiej (Kraków, 2008).

${ }^{5}$ P. Chmielowski, 'Towarzystwo Szubrawców i Jędrzej Śniadecki: Zarys obyczajowo-literacki', Tygodnik Ilustrowany (1878), pp. 19-20, 36-7, 75-6, 84-6, 107-8, 115, 117, 132-3; Id., Liberalizm i Obskurantyzm na Litwie i Rusi (1815-1823) (Warsaw, 1898).

${ }^{6}$ R. Ottmann, 'Przyczynek do historyi Towarzystwa Szubrawców: Na podstawie notat z papierów po Michale Balińskim', Reforma, no. 75, p. 1, no. 76, p. 1, 
analysed 'Street News' articles and highlighted the progressive and influential activities and thoughts of the Scoundrels. ${ }^{7}$ In particular, he mentions their activities towards the abolition of serfdom, the improvement of morality, and the spread of education and the sciences. He discussed these problems separately; therefore, he failed to describe the way the Scoundrels treated contemporary society as a whole. For Beauvois, the Scoundrels were less progressive than Skwarczyński's description of them. He gave reasons for his views: the university's ambivalent position between the Russian government and the elite society of the former Commonwealth, censorship by the university, and the influence of the landed nobles on the Scoundrels. ${ }^{8}$

'Street News' caught the attention of scholars of the history of journalism and literature as being the first and the most influential publicistic journal containing satires on current topics between the partitions and the November Uprising in the lands of the former Commonwealth in the Russian Empire. ${ }^{9}$ The articles in 'Street News' were written anonymously or under various pseudonyms. Though the authors of many articles are still unknown, some pseudonyms have been identified. ${ }^{10}$ Research studies have been conducted on

no. 78 , pp. $1-2$, no. 79 , pp. $1-2$, no. 80 , p. 1 , no. 81 , p. 1 (1882) (He published another article of almost the same content under the same title: Tygodnik Ilustrowany, 13 (1882), pp. 386-91); Z. Hordyński, O Towarzystwie Szubrawców (Lwów, 1883); J. Bieliński, Szubrawcy w Wilnie (1817-1822): Zarys historyczny (Vilnius, 1910); H. Mościcki, 'Recenzja: Józef Bieliński, Szubrawcy w Wilnie (1817-1822): Zarys historyczny, Vilnius, 1910', Biblioteka Warszawska, vol. 2 (vol. 282) (1911), pp. 167-78.

${ }^{7}$ Z. Skwarczyński, 'Sprawa chłopska w "Wiadomościach Brukowych”, Prace Polonistyczne, 15 (1959), pp. 135-53; Z. Skwarczyński, Kazimierz Kontrym: Towarzystwo Szubrawców: Dwa studia (Łódź, 1961); Z. Skwarczyński, 'Wstęp', Z. Skwarczyński (comp.), Wiadomości Brukowe: Wybór artykułów (Wrocław, 1962). See also: J. Ross, 'Towarzystwo Szubrawców a Towarzystwo Filomatów i Filaretów', Przegląd Lekarski, 11 (1968), pp. 805-9; J. Sikorska-Kulesza, 'Wileńskie "Wiadomości Brukowe" wobec sejmików szlacheckich w 2. dekadzie XIX w. na Litwie', Przeglad Wschodni, vol. 8, no. 1 (no. 29) (2002), pp. 97-117.

${ }^{8}$ Beauvois, Wilno, pp. 192-3.

9 J. Łojek (ed.), Prasa polska w latach 1661-1864 (Warsaw, 1976), pp. 90-1; A. Witkowska, Rówieśnicy Mickiewicza (Warsaw, 1998), p. 33.

${ }^{10}$ Z. Makowiecka and K. Kostenicz, 'Nieznany spis pseudonimów szubrawskich', S. Pigoń (ed.), Miscellanea z okresu Romantyzmu (Archiwum Literackie, vol. 1) (Wrocław, 1956), pp. 91-9; D. Świerczyńska, 'Pseudonimy "Wiadomości Brukowych”, Rocznik Towarzystwa Literackiego im. Adama Mickiewicza 7 (1972), pp. 137-66. 
literary works and the thoughts of the members, and the literary origins of their satire and rhetoric. ${ }^{11}$

Along with the above-mentioned changes in historiography, some scholars have placed the activities of the Scoundrels in the Lithuanian or Belarusian regional or national movements beyond the framework of Polish history. ${ }^{12}$ However, works by V. Maciūnas in the interwar period already regarded the activities of the Scoundrels as a Lithuanian cultural movement. ${ }^{13}$ Among these scholars, G. Beresnevičius wrote an article on research of Lithuanian mythology in the 19th century. In his article, he indicated the different attitudes of the members towards Lithuanian mythology. ${ }^{14}$ However, he did not pay attention to the differences in the concept of Lithuania before and after nationalism; he contrasted the Enlightenment and positivism with romanticism, and Polish colonial rule with the resistance of ruled Lithuania.

This article tries to investigate the concerns of the intellectuals of the Scoundrels about regional society and culture. Primarily based on an analysis of 'Street News' articles, we focus on two issues. The first issue is the intellectuals' opinions about the nation (naród in Polish) and the class system. It is thought that in the former Commonwealth, the nation consisted only of the nobility as a community of politically entitled persons. During the political reforms in the latter half of the 18th century, it had been enlarged to partially include the lower classes. This was mainly done through

${ }^{11}$ A. Wrzosek, 'Przedmowa do pism satyrycznych Jędrzeja Śniadeckiego', Jędrzej Śniadecki (A. Wrzosek comp.), Pisma satyryczne, vol. 1 (Warsaw, 1908); B. Skarżyński, 'Śniadecki jako publicysta', Jędrzej Śniadecki (B. Skarżyński comp.), Wybór pism naukowych i publicystycznych (Kraków, 1952); M. Stolzman, 'Książkowe facecje wileńskich Szubrawców', Roczniki Biblioteczne 29: 1-2 (1985), pp. 417-38; R. Naruniec, Michat Baliński jako mecenas polsko-litewskich więzi kulturowych (Warsaw, 1995); G. Nieć, Jakub Szymkiewicz "Szlachcic na Łopacie": Satyryczny reporter "Wiadomości Brukowych” (Kraków, 2006).

${ }^{12}$ Naruniec, Michat Baliński; Bukowiec, Dwujęzyczne poczatki, pp. 52-3; Szybieka also mentioned the regional character of the society. Szybieka, Historia, pp. 46-7.

${ }^{13}$ V. Maciūnas, 'Lietuviškieji dalykai Vilniaus Šubravcų satyroje', Mūsu Senové, vol. 2, no. 1 (6) (1937), pp. 7-16, vol. 2, no. 2 (7) (1938), pp. 179-93; Id., Lituanistinis sajūdis XIX amžiaus pradžioje (Kaunas, 1939. 2nd ed. Vilnius, 1997).

${ }^{14} \mathrm{G}$. Beresnevičius, 'Lietuvių ir lenkų istoriografija apie lietuvių mitologiją XIX a. pirmoje puseje: Mitologinès tradicijos įtaka lietuvių identiteto formavimuisi', Literatūra, 48 (5) (2006), pp. 13-28. 
the introduction of the property criterion of political rights. ${ }^{15}$ At the turn of the century, the lands of the Commonwealth underwent the partitions and the extinction of the state, the Napoleonic wars, and the abolition of serfdom in the Duchy of Warsaw. These developments must have influenced the understanding of the concept of the nation. Therefore, it is important to determine the intellectuals' concept of the nation and the way intellectuals placed the non-ruling classes in the whole nation. In the Russian part of the former Commonwealth, the languages and religions of the common people were different to those of the upper classes. At the beginning of the 19th century, the elites (who were mostly Polish speaking) were interested in the history of Lithuania and folk languages. Thus, the second issue is the intellectuals' attitude towards history and languages in the lands of the former Grand Duchy of Lithuania. Through these analyses, this article tries to investigate the relationship between Polish-speaking intellectuals and local society.

\section{Intellectuals in Vilnius and the Scoundrels}

Under Imperial Russian rule, Vilnius University was transformed into the Russian Imperial University in 1803, and flourished as a centre of Polish high culture. It produced intellectual elites until it was closed in 1832 by the Russian government. New intellectuals were born, in the form of professors, students and graduates of the university. Most of them came from noble families of middle and lower means; some came from burghers' families. The intellectuals around the university organised and participated in many associations, such as lodges of Freemasons, the Society of Typography, the Society of Philomaths, and the Charity Society, to spread the sciences and education and to improve societal cooperation. ${ }^{16}$ One of these organisations was the Scoundrels.

${ }^{15}$ As an important work which has a perspective on the beginning of the 19th century: A. Walicki, The Enlightenment and the Birth of Modern Nationhood: Polish Political Thought from Noble Republicanism to Tadeusz Kościuszko (Notre Dame, 1989). Recently, however, D. Althoen has maintained that in early modern times the words 'naród szlachecki' did not mean a 'noble nation' but meant usually 'noble origin', and that the widely accepted interpretation originated in the 19th century. D. Althoen, 'Natione Polonus and the Naród Szlachecki: Two Myths of National Identity and Noble Solidarity', Zeitschrift für Ostmitteleuropa-Forschung, 52, no. 4 (2003). See also: S. Plokhy, The Origins of the Slavic Nations: Premodern Identities in Russia, Ukraine, and Belarus (Cambridge, 2006), pp. 166-73.

${ }^{16}$ Maciūnas, Lituanistinis sajūdis, pp. 52-67; Skwarczyński, 'Wstęp', pp. XXIIIXXVIII. 
In August 1816, I.E. Lachnicki (a writer) and K. Kontrym (the university librarian) published a leaflet in Vilnius named 'Street News'. Kontrym continued to publish this leaflet sporadically; however, from January 1817, it was published regularly. In February, a newly founded organisation, the Scoundrels, assumed responsibility for publishing 'Street News'. The journal was published every Saturday ${ }^{17}$ until June 1822, when the Russian authorities suddenly forbade its publication. The Scoundrels were mainly organised by Kontrym, who had also taken the initiative to organise the activities of several other associations. The first president of the Scoundrels was J. Szymkiewicz, a doctor and friend of Kontrym. After his death in January 1819, a professor of chemistry, Jędrzej Śniadecki, became their president. The members included Z. Niemczewski (a mathematics professor), L. Borowski (a literature professor), J. Zawadzki (the proprietor of the university bookshop and printing office), and M. Baliński (a student and future historian), among others. ${ }^{18}$ The representative intellectuals of the Enlightenment gathered around the Scoundrels.

The purposes and organisation of the Scoundrels are described in the 'Code of Scoundrels' (Kodex Szubrawski), which was enacted in June 1817 and revised in October of the same year. ${ }^{19}$ The features of the Scoundrels are also visible in the 'Code'. According to the first clause, the Scoundrels were created to banish the faults, abuses, and pathologies of contemporary society which were harmful but often not recognised as illegal or defective. The issues mentioned were alcoholism, gambling, litigiousness, clinging to titles, and holding office as a privilege without adequate knowledge and qualification. It also included issues such as a lack of

${ }^{17}$ Each number of the journal usually contained four pages and cost 10 grosz in 1817. According to information on the journal, its annual subscription cost 2 roubles 50 kopecks. Together with the postage fee, it cost 3 roubles 50 kopecks in 1818 and 4 roubles in 1822. It is estimated that more than 3,000 copies of the popular No. 8 were published. Skwarczyński, 'Sprawa chłopska', p. 140.

${ }^{18}$ X. Auszlawis (M. Baliński), 'Mixtum chaos historya Szubrawstwa chronologicznie ułożona', Tygodnik Wileński, vol. 8, no. 143, 31 July 1819; Kodex Szubrawski (Wilno, 1819) (an excerpt from Tygodnika Wileńskiego, no. 137), pp. 3-5; Ottmann, 'Przyczynek', no. 78, pp. 1-2; A. Kraushar, Znachor: Antosiek, czyli Antoni Golec (Warsaw, 1903), pp. 5-6; Skwarczyński, Kontrym: Towarzystwo Szubrawców, pp. 92101, 114-32. Dates in this article are based on the Julian calendar.

${ }^{19}$ Kodex Szubrawski, p. 27. Here the version of 1819, which contains the supplements sanctioned in 1819 , is used. 
education amongst the ruling class, the corruption of the courts, a misplaced zeal for nationhood, and insincerity in promises made. ${ }^{20}$ The fifth clause required members to follow a lifestyle based on the purposes of the Scoundrels, such as to work hard, refrain from heavy drinking and gambling, and develop the habit of reading books. In addition, they were obliged to contribute witty articles to 'Street News'. The articles were published only after members approved them at a meeting. ${ }^{21}$

At the onset of the activities, the sources of the journal's articles were news and incidents happening in and around Vilnius. Subsequently, the area from where they gathered the news was marginally broadened. However, during the activities, news was generally collected from Vilnius and Lithuania. ${ }^{22}$ A famous series in 'Street News' is named 'Wandering on a Magic Spade'. The hero of this series, a nobleman who flies over the land on a magic spade, symbolised a Scoundrel who cast about for news and objects to criticise in the journal. Though a few articles were set in Warsaw or other places in the former Commonwealth, the subjects of the articles published in 'Street News' were mainly taken from the lands of the former Grand Duchy of Lithuania. ${ }^{23}$ Some articles in 'Street News' were influenced by literary works of the Enlightenment era, such as those by Swift, Lesage and Krasicki. They were set in fictitious lands or remote places, such as Africa and Asia, as critiques of contemporary society.

The journal wrote about themes which were familiar to readers in a humorous manner, satirised the pathologies of contemporary society, and carried articles characterised by instructive fables. Therefore, it gained popularity and support, but at the same time,

${ }^{20}$ Kodex Szubrawski, pp. 5-8.

${ }^{21}$ Kodex Szubrawski, pp. 10-13.

${ }^{22}$ Kodex Szubrawski, pp. 12-13. During the presidency of Śniadecki, the members felt that the geographical area that the news covered, which was mainly Vilnius and Lithuania, should be broadened to expand the journal's distribution to all the lands of the former Commonwealth. However, the news coverage was not broadened. Teczka Balińskiego, Biblioteka Jagiellońska, Ms. 3086, fo. 163.

${ }^{23} \mathrm{Cf}$. S. Kaji, 'Zakres przestrzenny Litwy w wyobrażeniu inteligencji wileńskiej na podstawie analizy Wiadomości Brukowych (1816-1822)', Acta Historica Universitatis Klaipedensis, vol. 14: History and Culture of Baltic Region: Lithuania and Poland: Social History, Cultural Sciences (2007). 
it repelled the people who were criticised in it, ${ }^{24}$ even though the 'Code' instructed that attacks on specific individuals be avoided.

\section{The Scoundrels and the 'nation'}

The nation and the class system The Scoundrels considered different classes of inhabitants of Lithuania (such as the nobility, burghers and peasantry), and social groups (such as landlords, intellectuals, merchants, craftsman, peasants and Jews). Their description covered rural life in villages or nobles' manors and social relationships in cities.

Some articles in 'Street News' mentioned the Lithuanian nation satirically and implicitly. 'Literal Report' in No. 152 presented a plan to compile a 'Dictionary of Celebrated Drunkards' covering each period and nation. It argued that when the article on contemporary Lithuania was edited, it should exclude Jews, Roma, Tatars and peasants. Its reasons were as follows: (a) the Jews did not have the ability to drink, (b) the Roma did not fund drinks, (c) the Tatar religion prohibited drinking, and (d) the peasants were forced to drink under the arenda system by the nobles who hired Jews to sell the alcohol. Moreover, this article said it was quite inappropriate to mention peasants' names in a dictionary of celebrated people. ${ }^{25}$ The article ridiculed the nobles' drunkenness, and tacitly satirised a nation composed only of nobles. It also recognised that the inhabitants of Lithuania were ethnically diverse.

Articles named 'Letters by an Indian: Translation from Sanskrit', published in Nos. 127 and 135, are good examples indicating the concept of the nation and the class system of the Scoundrels. These

${ }^{24}$ Pamiętnik Warszawski, vol. 9, December 1817, pp. 508-9; J. Lelewel, Listy Joachima Lelewela, Part 1, vol. 1 (Poznań, 1878), p. 265; S. Morawski, Kilka lat młodości mojej w Wilnie (1818-1825) (Warsaw, 1924), pp. 143-50, 415-8; Skwarczyński, Kontrym: Towarzystwo Szubrawców, pp. 181-5. Several journals published in Vilnius, Warsaw, Lviv and St Petersburg mentioned the activities of 'Street News' and reprinted some articles from it. See: Kuryer Litewski, the second supplement to no. 32, 20 April 1817; Dziennik Wileński, vol. 5 (1817), p. 206; Rozmaitości: Pismo dodatkowe do Gazety Korrespondenta Warszawskiego i Zagranicznego, no. 37, 39, 41, 43, 44, 45, 47 (1818); Gazeta Korrespondenta Warszawskiego i Zagranicznego, the supplement to no. 28 (1819), p. 500; Pamiętnik Lwowski, vol. 3, no. 10 (1818), pp. 84-112. According to Mościcki, a journal published in Petersburg also reprinted articles. Russkij Inwalid, no. 186 ff, (1818). Mościcki, 'Recenzja: Szubrawcy', p. 171.

25 'Doniesienie literackie', WB, no. 152, 1 November 1819. 
articles were published in 1819 under the pseudonym 'Februaryusz Fascykuł Szlachciński'. The foreword to the articles written by the articles' contributor, a nobleman in Žemaitija, mentions that he found a small book of old letters written in Sanskrit among old family documents inherited from his father. He translated and presented the letters written by an Indian to 'Street News'. In these letters, the Indian describes to his friend his travel experiences. The first five letters had been lost, and the '6th Letter' published in the journal told of strange customs in the Kingdom of Bibencja. There, the inhabitants were divided into two groups, 'the wise' and 'the foolish' by birth. Peasants, merchants, craftsmen and factory owners comprised the foolish. The ones who had been the foolish by birth became the wise; they knew the law and were able to hold and perform all offices. They neglected education and knowledge and spent their time idly. The nation of Bibencja consisted of the wise, who were the minority. The letter described scenes where the wise, consumed by anger, lashed the foolish with whips. ${ }^{26}$ The wise are a metaphor for the Lithuanian nobles. In the '7th Letter', the Indian author of the letters happened to visit the Holy Temple of Nationhood with a male inhabitant, whom he met in Perdudo in Bibencja. On a big door of the gorgeous building of the temple, 'a gold inscription could be seen, "Person of humble birth, get lost!", (emphasised in the original). This sentence contained the footnote, 'You need to know that the nobility is limited to people of noble birth in this country.' As they entered the temple, a man asked them to show proof of their noble birth. Only people of noble birth who had wasted their own fortunes and had fought a duel could enter the temple. However, they could enter as a foreigner or in the company of a foreigner. Inside the temple, a goddess, 'Nationhood', was worshipped. Then, in front of the goddess, they were asked to swear oaths to observe nationhood, which included the belief that each noble-born person could perform all offices irrespective of his education and ability, and objections to the freedom of people of humble birth. Nationhood also included idleness and the detestation of work, the non-repayment of debts, alcoholism, and clinging to titles. The nationhood that they had to observe was the one criticised by the 'Code'. Beside the holy temple, there was a hut without a roof,

26 'Listy indyyskie przełożone z języka Samskrdan przez Februaryusza Fascykuła Szlachcińskiego', $W B$, no. 127, 10 May 1819. It is revealed that these articles were written by J. Sękowski, an orientalist. Świerczyńska, 'Pseudonimy', p. 163. 
named 'National Inn', and a Jew decorated with the title 'National Publican' sold vodka to peasants at high prices. ${ }^{27}$

These satires showed that the Scoundrels admitted the existence of a privileged class, but they adhered to the openness of the nobility to the other classes, and criticised a nation which consisted only of nobles, especially only of nobles by birth.

In certain articles, they satirised the persistent efforts of a wealthy burgher for ennoblement, his liberalism, which, in fact, denied equal relationships with poorer neighbours, and his attempts to distinguish himself from poorer burghers after attaining the title of noble. ${ }^{28}$ Thus, the Scoundrels criticised the attitudes of non-nobles, if they were similarly noble-centred and snobbish. We may dare to remark that the Scoundrels were opposed to the rigorous demarcation of nobles and non-nobles.

Serfdom and education The attitude of the Scoundrels towards non-nobles can be observed from articles about serfdom. At that time, serfdom was already abolished or was being abolished in the Polish Kingdom and in the Baltic gubernias of the Russian Empire (Estland, Kurland and Livland). The Scoundrels published articles criticising serfdom in 'Street News'. The most famous example is the article entitled 'A Machine to Hit Peasants', written by A. Marcinowski in No. 8 in 1817 . The article is a fictional advertisement for a machine which saved time, power, and the tenderness of landlords or land managers (ekonom), and automatically hit peasants who were vulgar and impudent and did not obey orders without being hit. ${ }^{29}$ This is a sharp satire of the cruel treatment of peasants by the nobles.

The activities of the Scoundrels against serfdom were not limited to articles in 'Street News'. They stirred up public debates on serfdom, and this affair was discussed during the local diet (sejmik) of the Vilnius guberniya in 1817-18. A member of the Scoundrels, M. Römer, served as the chairman of the diet. After a heated discussion, the diet decided to submit a petition to the

27 'Listy indyyskie', WB, no. 135, 5 July 1819. Cf. Skwarczyński, Kontrym: Towarzystwo Szubrawców, pp. 175-6; idem., 'Wstęp', pp. lxi-lxiii.

28 'Doświadczenie liberalności: Wolne tłómaczenie $\mathrm{z}$ angielskiego', $W B$, no. 11, 17 February 1817; Kryszpin Dratewka, Cech mistrz kunsztu szewieckiego, 'Podziękowanie', WB, no. 14, 10 March 1817.

${ }^{29}$ (A. Marcinowski) 'Machina do bicia chłopów', WB, no. 8, 27 January 1817. 
emperor to abolish serfdom; however, this petition did not produce the expected results. ${ }^{30}$

In the first half of its activities, when Szymkiewicz and Kontrym were the main animators, 'Street News' often carried articles criticising serfdom. However, after Śniadecki took over as president of the Scoundrels, and played a major role writing many articles anonymously or under various pseudonyms, ${ }^{31}$ the criticisms of serfdom became milder and less frequent, although the tendency continued to describe the miserable realities of villages: their poverty and moral depravity. ${ }^{32}$

Many articles in 'Street News' satirised Jews. Some of them denounced the Jews for exploiting the peasantry as land managers and making the peasants indulge in drinking in inns. They also criticised the Jews for loaning money to extravagant nobles. ${ }^{33}$ These critical opinions were often seen in the discussions of Jewish problems at that time. The place of the Jews in villages as exploiters of the peasants under the control of the nobles connected the solution of Jewish problems with the abolition of serfdom. However, the criticism of the Scoundrels was also directed towards nobles who hired Jews to manage their manorial lands by the arenda system, or who depended on the Jews financially and commercially. ${ }^{34}$

The Scoundrels made efforts to spread education and its values among poorer people as well as the nobles. Some articles in 'Street News' ridiculed nobles who did not value education and who bought votes and regional and court positions in local diets, even though they

${ }^{30}$ Lelewel, Listy, Part 1, vol. 1, p. 297; H. Mościcki, Pod znakiem Orła $i$ Pogoni: Szkice historyczne (Lwów, 1923 [2nd ed.]), pp. 59, 66-79.

${ }^{31}$ Wrzosek estimated Śniadecki wrote quantitatively about one sixth of all articles. Wrzosek, 'Przedmowa', pp. 24-5.

${ }^{32}$ For example: 'Kłopoty życia wieyskiego', WB, no. 159, 20 December 1819; (Jędrzej Śniadecki) 'Podróży próżniacko-filozoficzney ciąg dalszy: Wyprawa na wieś', $W B$, no. 235, 4 June 1821. See also: Skwarczyński, 'Sprawa chłopska', pp.149-52; Skwarczyński, Kontrym: Towarzystwo Szubrawców, pp. 56, 158-61; Skwarczyński, 'Wstęp', pp. xlvii-xlviii.

${ }^{33}$ For example: 'List od karczmarza Benzela Chaimowicza do starozakonnego obywatela M. Wilna utrzymującego handel winny', $W B$, no. 53, 8 December 1817 ; 'O przymnożeniu swobód i wolności żydkom', WB, no. 267, 14 January 1822, no. 268, 21 January 1822, no. 271, 11 February 1822, no. 272, 18 February 1822.

34 (J. Szymkiewicz) 'Wędrówka na łopacie', WB, no. 71, 13 April 1818; 'Pochwalmy Żydów', WB, no. 80, 15 June 1818; 'Doniesienie literackie', WB, no. 152, 1 November 1819 . 
lacked the knowledge required for these positions. ${ }^{35}$ Other articles in 'Street News' paid critical attention to the education imparted at home and in pensions for upper-class girls because it was frivolous education, which was practical only in a fashionable society. ${ }^{36}$

Because primary education for poor people, especially for the peasants, was looked after by charities at that time, some of the Scoundrels were engaged in charity and made efforts to improve the conditions of impoverished people, rather than merely resorting to criticism in the journal. ${ }^{37}$ Szymkiewicz, in his will, freed the peasants of his lands, acknowledging their tenure of lands, and left an educational fund, among others, for the children of poorer families of nobles, burghers and peasants. ${ }^{38}$ Kontrym and J. Chodźko took an active part in the Charity Society (Towarzystwo Dobroczynności) in Vilnius. Niemczewski also left a part of his property for education and bequeathed to the House of the Poor operated by the Charity Society in Vilnius. ${ }^{39}$ Chodźko, who was an honourable supervisor of schools in the Dzisna county in the Minsk gubernia, contributed an article to the organ of the Charity Society. It was about village schools for the children of peasants. In 1821, he also published a textbook for primary schools entitled 'Mr Jan from Świsłocz'. The Philomath Society supported the diffusion of the textbook. ${ }^{40}$ Chodźko became a school inspector for the Vilnius gubernia in 1822, and

${ }^{35}$ For example: 'Do wydawcy Wiadomości Brukowych', WB, no. 20, 21 April 1817; 'Rozmowa Cześnika z Chorążym Powiatowym o przyszłych seymikach', $W B$, no. 25, 26 May 1817; 'Rozmowa Rotmistrza, Skarbnika i syna jego Skarbnikowicza, przybyłego z uniwersytetu', $W B$, no. 30, 30 June 1817; 'List obywatela powiatu Brasławskiego do obywatela bawiącego się brukiem w mieście Wilnie', $W B$, no. 40, 8 September 1817.

${ }^{36}$ For example: 'Do Pana Redaktora', $W B$, no. 113, 1 February 1819; 'Dalszy ciąg podróży Szweczpuńscynisa: o edukacyi', WB, no. 187, 3 July 1820; Jaśmin Lizistopek (M. Baliński), 'Do Towarzystwa Sentymentalnego, doniesienie z Eldorado', $W B$, no. 198,18 September 1820; 'Ogłoszenie o nowey pensyi dla panien', $W B$, no. 199, 25 September 1820; 'Dalszy ciąg podróży Szweczpuńscynisa: Ciąg dalszy rozdziału o edukacyi', WB, no. 204, 30 October 1820.

${ }^{37}$ Some articles mentioned primary education in its satire. For example: 'List obywatela powiatu Brasławskiego', WB, no. 40, 8 September 1817; (L. Borowski) 'Bibliografiia', $W B$, no. 239, 2 July 1821.

38 'Nekrolog: Jakub Szymkiewicz', WB, no. 102, 16 November 1818. See also: Nieć, Jakob Szymkiewicz, p. 77.

39 'Nekrolog: Zacharyasz Niemczewski', WB, no. 211, 18 December 1820.

${ }^{40}$ Maciūnas, Lituanistinis sajūdis, p. 61; Skwarczyński, Kontrym: Towarzystwo Szubrawców, pp. 54, 130. T. Zan, who belonged to both societies, helped Chodźko in the school inspection. 
the Mogilev and Vitebsk gubernias in 1823 (after the dissolution of the Scoundrels). He left a detailed report for the Vilnius guberniya, including information on parish schools. However, he insisted that the educated peasantry should still be engaged in agriculture, not handicrafts or other occupations. He also did not admit any social advance through education. At the same time, Chodźko proposed the same curriculum for burghers' children and nobles' children. He accepted that the educated and talented children of burghers could pursue higher education, and numerous opportunities were available to them as well as to the children of nobles. ${ }^{41}$

It follows that the Scoundrels thought their nation should be composed not only of nobles but also of other classes. They were concerned with the ruled classes, especially the peasantry. They criticised serfdom in the journal and directed public attention to it. Though they could not abolish serfdom, they made efforts to broaden education among the poorer nobles and common people. They tried to include poor nobles and common people in the national community through the abolition of serfdom and education. Even though there were differences of opinion among the members, they thought the barriers between classes, at least that between the nobles and educated and talented burghers, should not be too rigorous.

The attitudes of the Scoundrels were pioneering in Lithuania at that time. However, some of their criticisms and social activities (e.g. moral improvement, the spread of education, and reform of serfdom) are found amongst reformers in Warsaw in the latter half of the 18th century. In reality, the nobility of the former Grand Duchy of Lithuania had culture, tradition, customs and social pathologies similar to those of the nobility of the former Polish Kingdom. However, if we consider all classes of inhabitants of historic Lithuania, then Lithuanian society was ethnically diverse. Lithuania also has a history which is different from that of Poland. Therefore, the next chapter will consider the attitudes of the Scoundrels towards aspects which were not Polish but Lithuanian and local, mainly the history and languages in Lithuania.

\section{The Scoundrels and Lithuania}

The intellectuals' interest in Lithuania At the beginning of the 19th century, interest in the history, language and folklore of Lithu-

${ }^{41}$ J. Chodźko, 'O szkołkach parafijalnych i wieyskich. Uwagi', Dzieie Dobroczynności Kraiowey i Zagraniczney z wiadomościami ku wydoskonaleniu iey stużqcemi (Vilnius, 1820), pp. 315-26. 
ania grew around Vilnius University, in Žemaitija, and in Lithuania Minor. The theme of the origin of the Lithuanian nation captured the attention of $\mathrm{K}$. Bohusz and J. Lelewel, who published work on it. The New Testament was translated into Žemaitijan by J.A. Giedroyć, the Bishop of Žemaitija, in 1816. K. Donelaitis' Four Seasons was published in 1818 in Lithuania Minor. At that time, Eastern Slavic folklore was also collected by Z. Dołęga Chodakowski and others. Intellectuals took a great interest in the cultures of the common people in the lands of the former Commonwealth.

An interest in cultures in Lithuania can also be seen in the Scoundrels. According to the fourth clause of the 'Code', the senior members, called urban, were given membership names taken from Lithuanian mythology.

These names are derived from words by which, in mythological times, our ancestors, that is, old Lithuanians, invoked divine beings or referred to persons held in honour for their offices or outstanding virtues. Each Scoundrel makes efforts, at least during a whole year, to find (even with the help of the others) and read (by themselves without fail), in the chronicles and historiographies, descriptions of historical tales about the being or person by whose name the member is honourably called. By making these efforts, the Scoundrel not only learns about the country, but also has the noble intention of compiling the mythological history of the Lithuanian nation. This will later be published with illustrations through the efforts and at the cost of the Society of Scoundrels for the benefit of compatriots and scholars across the world. ${ }^{42}$

The first president of the Scoundrels, Szymkiewicz, used the name Perkunas. ${ }^{43}$ These membership names were taken from the widely read 'Chronicle of Poland, Lithuania, Žemaitija and all Rus' written by M. Stryjkowski in the 16 th century. ${ }^{44}$ At that time, names related to Lithuanian mythology became so popular among the nobles and

${ }^{42}$ Kodex Szubrawski, pp. 9-10.

${ }^{43}$ The members' names were usually different from the pseudonyms used in the articles of 'Street News'. For other members' names, see: Auszlawis (Baliński), 'Mixtum chaos'; Bieliński, Szubrawcy, pp. 73-4; Makowiecka i Kostenicz, 'Neznany spis'; Skwarczyński, Kontrym: Towarzystwo Szubrawców, pp. 114-32; Świerczyńska, 'Pseudonimy', pp. 139-40.

${ }^{44}$ Ibid., pp. 141-2; Nieć, Jakub Szymkiewicz, pp. 43-4; Beresnevičius, 'Lietuvių ir lenku', p. 17. Some scholars mention as the source De diis Samagitarum caeterorumque Sarmatarum et falsorum christianorum by Jan Łasicki. Mościcki, 'Recenzja: Szubrawcy', p. 171; Naruniec, Michat Baliński, pp. 81-2. 
intellectuals that a Freemasons' lodge was named Palemon after the mythological founder of Lithuania. ${ }^{45}$

The committee which edited the 'Code' was composed of K. Strawiński (who provided financial support for the foundation and activities of the journal), Kontrym, Szymkiewicz and Baliński. ${ }^{46}$ Kontrym had broad contacts with intellectuals who wrote in Lithuanian as well as Polish, such as L. Uwoyń (Uvainis) and S. Staniewicz (Stanevičius). ${ }^{47}$ Then Kontrym and Szymkiewicz took the initiative of giving Lithuanian mythological names to the members and studying Lithuanian mythology. ${ }^{48}$

The publication of the Scoundrels sometimes contained Lithuanian personal names, parodies of Lithuanian words, and Lithuanianised endings of Polish words as pen names or the names of characters in the articles. They were tools of satire at the same time. The symbol of 'Street News', a nobleman on a magic spade, originated from a Lithuanian folk tale of a witch flying on a spade. ${ }^{49}$

Scholars have pointed out that after Śniadecki (who had a negative attitude towards romanticism) became the president, the Scoundrels began to treat the characteristics of Lithuanian culture negatively. ${ }^{50}$ Next, we analyse the attitude of the Scoundrels towards Lithuanian history, including mythology and languages in Lithuania, both of which are related to characteristics of Lithuania and can be regarded as attributes of folk culture.

The Scoundrels and Lithuanian history Articles in 'Street News' employed historical rhetoric, and some of them did so just to create a fictional story, which was not related to history. This type of rhetoric shows the remarkable growth of interest in history and the collection of historical documents in the early 19th century, irrespective

${ }^{45} \mathrm{~S}$. Małachowski-Łempicki, Wolnomularstwo na ziemiach dawnego Wielkiego Księstwa Litewskiego 1776-1822: Dzieje i materiaty (Vilnius, 1930. 2nd ed. Warsaw, 2005), p. 54.

${ }^{46}$ Hordyński, O Towarzystwie, p. 18; Skwarczyński, Kontrym: Towarzystwo Szubrawców, p. 102.

${ }^{47}$ E. Aleksandravičius, 'Kazimierz Kontrym i litewski ruch narodowo-kulturalny na początku XIX wieku', Lituano-Slavica Posnaniensia, 8 (2001), pp. 15-22.

${ }^{48}$ Skwarczyński, Kontrym: Towarzystwo Szubrawców, p. 167; Świerczyńska, 'Pseudonimy', p. 142; Beresnevičius, 'Lietuvių ir lenkų', pp. 16-8.

${ }^{49}$ Witkowska, Rówieśnicy, p. 34. As to the explanation of the origin of the magic spade by Szymkiewicz, see: 'Łopata czarownicza', WB, no. 9, 7 February 1817.

${ }^{50}$ Skwarczyński, Kontrym: Towarzystwo Szubrawców, pp. 166-7; Id., 'Wstęp', pp. lxiii-lxiv; Beresnevičius, 'Lietuvių ir lenkų', p. 20. 
of whether the article saw the interest positively or negatively. This type of rhetoric continued to be used even after Śniadecki became president. Other articles borrowed scenes from stories of the history of Lithuania as a critique of the present situation. Here, the latter type of rhetoric of history will be analysed.

'Wandering on a Magic Spade: A Continuation' by Szymkiewicz in No. 15 contained a scene in which a nobleman flew over the River Nemunas in Žemaitija on a magic spade. The nobleman visited the place where Gediminas died while defending his country against other nations. He lamented the death of Gediminas, but, at the same time, took a delight in the presence of virtuous and courageous people in ancient Lithuania. He also visited the Hill of Palemonas, and searched for the basement of the temple of Perkunas, whose remnants he could not find. ${ }^{51}$

In an anonymous article entitled 'Iron Box with Manuscripts' in No. 75, newly found manuscripts were presented to readers as archives of ancient Lithuanian history which convinced people of how 'our ancestors' were civilised. There were three kinds of manuscript: Lithuanian (the oldest), Polish and Latin. Some of the Lithuanian manuscripts are presented here. One of the manuscripts described how King Mingayłas found a separate party of nobles and rich during an inspection tour, and ordered that all classes should enjoy themselves together. Another was a work encouraging the emancipation of serfs in ancient times. 'Two Volumes about Lithuanian Mythology Written by Poklus' raised objections to the chronicle of Stryjkowski. They argued that some names of Lithuanian gods, which became member names of the Scoundrels, such as Poklus and Gurcho, were in reality names of persons or spirits. ${ }^{52}$ In this article, Poklus was referred to as a 14th-century professor and author of Lithuanian mythology; the article ridiculed Kontrym, who had adopted this name. ${ }^{53}$ However, in general, the Scoundrels made fun of almost everything, including themselves, and this article was not severely satirical. Although it maintained a distance from the anxious

${ }^{51}$ (J. Szymkiewicz) 'Dalszy ciąg wędrówki na łopacie czarowniczey', WB, no. 15, 17 March 1817. Originally this series was written by Szymkiewicz, and after his death mainly by Śniadecki. Świerczyńska, 'Pseudonimy', pp. 154-6; Nieć, Jakub Szymkiewich, pp. 82-90.

52 'Skrzynia żelezna z manuskryptami', $W B$, no. 75, 11 May 1818.

${ }^{53}$ Beresnevičius thought this article criticised Kontrym and his plan to research ancient Lithuania. Beresnevičius, 'Lietuvių ir lenkų', pp. 18-19. 
searches for historical documents of ancient times, on the whole, it shared an interest in ancient Lithuania, and described it ideally to stress the contrast with the contemporary corrupt situation. The above-mentioned 'Literal Report' in No. 152 of 'Street News' also argued that there were no nobles in ancient Lithuania. To criticise the pathologies in early 19th-century Lithuanian society, these articles probably imitated such contemporary historical research as that by Narbutt, who idealised ancient Lithuania. ${ }^{54}$

Some articles in 'Street News' described an interest in ancient Lithuania itself. One of them was an article in Lithuanian entitled 'Treatise about Eloquence in Court' in No. 101. This article was published as a foreword by the translator 'Guard of Learning' (Usztarytois Mokitinis) to the original document written in Lithuanian. It told of a museum, 'Baublys' (Baublis), and its curator, 'Keeper, Champion, and Seeker' (Sargas Kawotois ir Uszkotois), which implied D. Paszkiewicz (Poška), a well-known antiquary in Samogitia. According to the translator, the curator welcomed everyone into his museum, irrespective of educational level, wealth, age or gender; however, the collections in the museum were insignificant, and the curator narrated some unfounded history of Lithuania on the basis of these collections. According to a simple comparison of Lithuanian and Samogitian with Sanskrit, the curator concluded that the ancient Lithuanians came from India. Scrolls were kept in barrels, which implied drunkenness. The translator obtained a priceless text from him named 'Treatise about Eloquence in Court', whose value the curator did not understand. The translator continued that the first volume of the text conveyed the wisdom of the ancient Lithuanians in listening to one another, a skill already forgotten in the early 19th century. ${ }^{55}$ Thus, this article critiqued Paszkiewicz and Baublys. However, ancient Lithuania was described as opposed to the early 19th-century litigious society, and was treated positively, to a certain extent.

Scholars regard Baliński as the author of the article. ${ }^{56}$ Baliński, a future historian, entered Vilnius University in 1812. He collaborated

${ }^{54}$ Cf. T. Narbutt, 'Badanie starożytności litewskich: Domniemanie o dawnych Litwinach', Tygodnik Wileński, no. 71 (1817).

55 'Apey iszkałba sudyne moksłas (o wymowie sądowey traktat), przekład dosłowny z litewskich zwojów dziuplowych', WB, no. 101, 9 November 1818.

${ }^{56}$ See: M. Brensztejn, Dionizy Paszkiewicz: Pisarz polsko-litewski na Żmudzi (Wilnius, 1934), p. 22; Bibliografia literatury polskiej: Nowy Korbut: vol. 7, 
with Lelewel to edit Tygodnik Wileński. He was engaged in writing the history of Vilnius city from $1818 .^{57}$ Thus, it is inappropriate to consider that Baliński generally criticised research on ancient Lithuania in the article in No. 101. ${ }^{58}$ It is more likely that in the article he commented on Paszkiewicz's method of research and collection of historical sources, such as basing history unquestioningly on simple language comparisons.

Paszkiewicz heard from his neighbour that the article was a satire on his Baublys and antiquarianism. According to Paszkiewicz, an anonymous poem was spread which supported Baublys against the article. Friends of Paszkiewicz asked to publish it in 'Street News', but the journal refused. ${ }^{59}$

During the latter half of 'Street News' activities, there was less interest in Lithuanian history and rhetoric which used Lithuanian history as the scene for a story. Articles appeared which mocked any interest in Lithuanian history and showed critical attitudes towards its enthusiasts. The anonymous article entitled 'The Newest Travel to Babylon', published in No. 125 in 1819, satirised Paszkiewicz, who was made an antiquary named 'Drink-Beer' (Giark-Ałaus). In the article, the antiquary gets news of the discovery of the Babylonian Tower. He recalls that an ancestor of his nation, Żemiaytis, lived in the tower; therefore, he goes straightaway to Babylon to search for relics of the Lithuanian nation. In the newly built tower, he finds a priceless relic for the nation, which is a wooden spoon used by Żemiaytis. On his return he donates it to Baublys. The

Romantyzm (Warsaw, 1968), p. 124; Świerczyńska, 'Pseudonimy', p. 156; Beresnevičius, 'Lietuvių ir lenku', p. 20. This article has similarities with the following articles by Baliński: (M. Baliński) 'Madrygał Jeśpana Auszlawis nadzwyczaynego witaynika i strażnika porządku, piastującego Łopatę: Urywek zwoju dziuplowego: Przekład z litewskiego', WB, no. 75, 11 May 1818; (M. Baliński) 'Dzieje Wyspy Eldorado przez Pana Jacka Sobiesława', Tygodnik Wileński, no. 144, 15 August 1819. However, Naruniec did not mention this article in his work on Baliński.

${ }^{57}$ Naruniec, 'Michał Baliński', pp. 16, 27-8, 31-2, 39. Later he wrote a work about religion and ancient times in Lithuania. M. Baliński, T. Lipiński, Starożytna Polska pod względem historycznym, jeograficznym i statystycznym, vol. 3: Wielkie Księztwo Litewskie (Warsaw, 1846), pp. 7-107.

${ }^{58}$ Cf. Beresnevičius, 'Lietuviu ir lenku', p. 20; Bukowiec, Dwujęzyczne poczatki, pp. 240-2.

${ }^{59}$ D. Paszkiewicz, Pszczótka w Baublu, Biblioteka Naukowa PAU i PAN w Krakowie, rękopis 1864, pp. 88-9, 217 (published in: D. Poška [J. Kruopas et al. eds.], Raštai [Vilnius, 1959], pp. 536-41). Brensztejn, Dionizy Paszkiewicz, pp. 22-6. 
antiquary published a book about his journey to Babylon, which (according to the article) was 'the best typographical work in our country written in Žemaitijan'. The article continued the satire, by presenting a part of this book. ${ }^{60}$ This article did not mention the idealised image of ancient Lithuania, and it treated research into ancient Lithuania very negatively.

The above-mentioned 'Letters by an Indian' published in Nos. 127 and 135 also dipslayed critical attitudes towards the history of the origin of the nation. The 'Foreword by the Translator' in No. 127 ridiculed simple language comparisons. The translator, a nobleman in Žemaitija, after finding the letters in Sanskrit, 'began to learn Sanskrit. It was easy for me, because (as you know) Polish is a dialect of Sanskrit, as German is a dialect of Persian. ${ }^{61}$ The '7th Letter' in No. 135 also critiqued history which is based unquestioningly on legends and simple comparisons between words in different languages. In Bibencja, the Indian met a scholar who did not understand Sanskrit but argued that the people of Bibencja came from India on the basis of a legend and the similarity of four Sanskrit words to words in the language of Bibencja. ${ }^{62}$

At the end of the 18th century, historical and comparative linguistics in European languages, Sanskrit, and other oriental languages started fascinating European scholars. In 1815, in a Warsaw journal, an anonymous author introduced the German C.G. Anton's thesis which compared Slavic languages (including Polish) to Sanskrit, and explained that the ancestors of the Slavs lived under the king of Babylonia, Persia and Media. ${ }^{63}$ In Vilnius, Lelewel cited it and wrote a research plan on the origin of Sanskrit, the Slavic languages and other European languages in a more professional way. It re-

60 'Naynowsza podróż do Babilonu', WB, no. 125, 26 April 1819.

61 'Listy indyyskie', $W B$, no. 127, 10 May 1819.

62 'Listy indyyskie', WB, no. 135, 5 July 1819. See also: (Jędrzej Śniadecki) 'Dziennik podróży Szlachcica na Łopacie z Wilna przez Lidę, Stambuł, do miasta afrykańskiego Puroz-Mieros: Ciąg pierwszy', WB, no. 160, 27 December 1819; idem., 'Dalszy ciąg podróży Szlachcica na Łopacie (Obacz N.160)', WB, no. 171, 13 March 1820.

${ }^{63}$ Anonim, 'O powinowactwie ięzyków Słowiańskich z ięzykiem Samskrydańskim czyli starożytnym Indyyskim', Pamiętnik Warszawski, vol. 3, November (1815), pp. 298-301. The next year, a pioneering Polish work on Sanskrit was published; W. Skorochód Majewski, O Stawianach i ich pobratymcach: Czesść I, Obeymuiqca czytane na posiedzeniach działowych w latach 1813, 1814, 1815, tudzież na posiedzeniu publicznem Towarzystwa Królewskiego Przyiaciót Nauk dnia 30 kwietnia 1816 r. rozprawy o języku samskrytskim (Warsaw, 1816). 
ceived criticism in the same journal. ${ }^{64}$ The 'Letters by an Indian' also satirised linguistic comparison and ancient history based on it, which was popular at that time. Lelewel may have been included in the satire. In these cases, comparisons between Sanskrit and Polish were the target of the criticism. Interest in Lithuania was not the main reason for the satire. However, in the article published in No. 101, a comparison was made between Sanskrit, Lithuanian and Žemaitijan. Accordingly, this satire allowed the comparisons between Sanskrit, Lithuanian and Žemaitijan to come to the fore, and set the controversy on ground more specific to Lithuania.

These articles in 'Street News' show that attitudes towards the interest in Lithuanian history were profoundly different among members of the Scoundrels. During the first half of their activities, when Kontrym played the main role in the Scoundrels, articles tended to show a positive interest in Lithuanian mythology and history. They wrote of ancient Lithuania as the ideal society, against which contemporary society was critiqued. However, during the latter half of their activities, when Śniadecki was the president, interest in Lithuanian history declined and sometimes it was even satirised. According to Skwarczyński, for the Scoundrels (including Baliński), lovers of ancient Lithuanian history, such as Paszkiewicz, were objects of criticism because they were conservative antiquarians of noble origin. ${ }^{65}$ However, Baliński was interested in Lithuanian history as well; he criticised Paszkiewicz because of the amateur procedure he used for his source criticism and linguistic analyses.

The community of the Polish language and the languages of Lithuania As is mentioned above, a few Lithuanian words and expressions can be found in 'Street News', such as names taken from Lithuanian mythology. Among the Scoundrels, some Žemaitijan-born people spoke Lithuanian as well as Polish, such as Szymkiewicz and Niemczewski. ${ }^{66}$ Kontrym was friendly with Polish-Lithuanian

${ }^{64}$ (J. Lelewel), [no title], Tygodnik Wileński, no. 1, 21 November 1815, pp. 126; Bogumiła Śmieszyńska, 'Do JPana Redaktora Tygodnika Wileńskiego, z rymami danemi, czyli przez skrócenie z Rym-danami’, Tygodnik Wileński, no. 8, 9 January 1816, pp. 126-31.

${ }^{65}$ Skwarczyński, Kontrym: Towarzystwo Szubrawców, p. 167; Id., 'Wstęp', p. LXIV.

${ }^{66}$ Niemczewski presented the Roman and Polish poems translated by Paszkiewicz into Lithuanian at the School Commission at Vilnius University in 1810. M. Lukšienè, Lietuvos švietimo istorijos bruožai: XIX a. pirmojoje pusejje (Kaunas, 1970), pp. 92-3. 
bilingual intellectuals besides Szymkiewicz and Niemczewski. However, the majority of the Scoundrels did not know Lithuanian, or wrote only in Polish. 'Street News' was a Polish journal, and the Lithuanian title was unique.

'Street News' referred to differences in the languages of peasants and nobles in Lithuania at that time. Śniadecki referred to a peasant who spoke 'a foreign language', that is, a language other than Polish. ${ }^{67}$ An anonymous article entitled 'An Analysis of the Work Entitled "Historical, Statistical, Physical, and Moral Description of the Country of Feather-Brains with Comments on the Progress of Its Inhabitants", published in No. 221, said that in the "Country of Feather-Brains', the languages of the nobles and the peasants had been different from each other since the mid-14th century. At that time, the nobles' language was similar to the Polish language. ${ }^{68}$ However, the article did not mention any other details about the language(s) of the peasants; it did not indicate whether it was Lithuanian or Ruthenian (Belarusian). Thus, it is not clear how the Scoundrels assessed the linguistic situation of the peasantry, though the Scoundrels did not pay much attention to Ruthenia or its culture.

According to 'Letters by an Indian', the Indian denied relations between his nation and the people of Bibencja because of a lack of similarity in their character, customs, features and languages. Therefore, it is possible to say that this article conveyed the message that a nation possessed common characteristics, such as a similar culture and language. These characteristics were understood to constitute nationhood in the article. ${ }^{69}$

However, the Scoundrels considered the Polish language a part of their nationhood. They wrote articles in 'Street News' in Polish, and they maintained relations with the Polish-speaking society of the former Commonwealth. For example, many articles were inspired by a Polish dictionary compiled by S.B. Linde. ${ }^{70}$ The Scoundrels

${ }^{67}$ (Jędrzej Śniadecki) 'Wyprawa na wieś', WB, no. 235, 4 June 1821.

68 'Rozbiór dzieła pod tytułem: Opisanie historyczne, statystyczne, fizyczne i moralne krainy Gawronadji z przyłączeniem uwag nad postępem jej mieszkańców', $W B$, no. 221, 26 February 1821.

69 'Listy indyyskie', $W B$, no. 135, 5 July 1819. Yet this article argued also that nationhood was not the privileges of the nobles of the Commonwealth; instead, it was to accept good things and acts even if they were of foreign origin, and bring honour to one's own nation on the way to integrating into an enlightened society.

${ }^{70}$ See: 'Walka abecadłowa', $W B$, no. 55, 22 December 1817; 'Nowy słownik, ludziom dobrego tonu przypisany’, $W B$, no. 138, 26 July 1819, no. 139, 2 August 
also paid attention to the maintenance and purification of the Polish language against foreign languages, dialects and folk languages. ${ }^{71}$ They promoted the Polish language and literature, and ridiculed people who preferred using foreign languages such as German or French. ${ }^{72}$ Nobles who clung to the use of French as a status symbol at the cost of Polish, and women of higher classes who admired foreign literature, were the target of criticism by the Scoundrels. ${ }^{73}$ In particular, Jędrzej Śniadecki, together with his brother Jan, was eager to enlarge the role of Polish among the nobles and intellectuals.

As is mentioned earlier, in the article 'The Newest Travel to Babylon', the person modelled on Paszkiewicz was satirised for the publication of books in Žemaitijan (Lithuanian). The Scoundrels ridiculed Paszkiewicz and his friends, who wrote books in Lithuanian, which was just a folk language in the early 19 th century. ${ }^{74}$

Many members of the Scoundrels regarded Polish as their own proper language and tried to purify the Polish language used in Lithuania. They regarded the Lithuanian language as a language of simple people, which could only be a tool for satire or a research object related to Lithuanian mythology or history. The use of Lithuanian as a written language was ridiculed more heavily than the interest in Lithuanian history, probably because Lithuanian history was the past connected to the nobles and intellectuals; the Lithua-

1819; 'Nowy słownik', WB, no. 175, 10 April 1820; 'Próba nowego słownika polskiego', $W B$, no. 251, 24 September 1821 . The above-mentioned 'Dictionary of Celebrated Drunkards' in no. 152 can also be mentioned as an example.

71 'O rosszerzeniu mowy i pisowni polskiej', $W B$, no. 81, 22 June 1818; 'Rozbiór dzieła', $W B$, no. 221, 26 February 1821. See also: Skwarczyński, Kontrym: Towarzystwo Szubrawców, pp. 165-7; Idem., 'Wstęp', pp. LXV-LXIX; Stolzman, op. cit., pp. 426-8, 433-4, 436.

${ }^{72}$ For example: 'Wyjątek ze sławney Historyi znakomitych czynów Pantagruela. Z xięgi pierwszey. Rozdział szósty. Jak Pantagruel spotkał Mazura, który chciał pięknie i uczenie mówić po polsku', WB, no. 14, 10 March 1817; (Jędrzej Śniadecki) 'Lament i rapport Szlachcica na Łopacie', WB, no. 277, 25 March 1822.

${ }^{73}$ For example: 'List pocztą przysłany do Redakcji Wiadomości Brukowych', $W B$, no. 75, 11 May 1818 (Świerczyńska regards Baliński as its author, op. cit., p. 163); 'Podróży próżniacko-filozoficzney ciąg dalszy: Doniesienie ciagnie się daley czyli pierwsze posiedzenie Sentymentalnego Towarzystwa', WB, no. 111, 18 January 1819. See also footnote 36.

${ }^{74}$ Paszkiewicz left works written in Polish and Lithuanian, and argued that official documents in Lithuania had been written in Lithuanian before the influence of the Polish language became strong. (D. Paszkiewicz) 'Rozmyślania wieśniaka rolnika o narodzie litewskim i żmudzkim, tudzież o jego języku', Dziennik Warszawski, no. 45 (1829), pp. 97-103. 
nian language was not their own in many cases. The Scoundrels paid attention to the common people and recognised the diversity of the inhabitants and their languages in historical Lithuania, but their activities to spread education and enlightenment should have led to the integration of people into Polish-speaking society.

At the same time, Śniadecki (who was from Poland, unlike many other members of the Scoundrels) participated in the Scoundrels as an intellectual of Vilnius. He could take the initiative in the regional society. This showed the openness of Polish-speaking society in Lithuania.

However, if we consider all the activities of the Scoundrels besides the activities of 'Street News', not all of them insisted on the exclusive use of the Polish language. Some of the Scoundrels promoted the use of Lithuanian as a written and educational language for Lithuanian-speaking people. In May 1822, Kontrym submitted a memorandum to the curator of the Vilnius Educational District, A.J. Czartoryski, to found a Chair of the Lithuanian language in the university. In his memorandum, Kontrym emphasised that its introduction would be useful for training future priests, teachers and officials who would serve the Lithuanian-speaking area, and for sciences such as linguistics and historical research. ${ }^{75}$ This proposal was not realised, but Kontrym influenced other publications and translations in Lithuanian. ${ }^{76}$ The translations into Lithuanian of ' $\mathrm{Mr}$. Jan from Świsłocz' by Chodźko was published in 1823, just a year after the dissolution of the Scoundrels. It is possible that there was a connection between the fact that the criticism of serfdom became weak and less frequent after the leadership of the Scoundrels moved from Kontrym to Śniadecki and the fact that the Scoundrels turned away from the development of Lithuanian peculiarities at the same time. However, further research is required to establish this connection. For Kontrym and others who made efforts to abolish serfdom and educate the common people, the Lithuanian language was not a centrifugal force but a necessary element for the common people in a Polish-speaking society.

Conclusion On the basis of our analyses of articles in 'Street News', we reached certain conclusions. The members of the Scoundrels pp. 23-8.

${ }^{75}$ S. Pigoń, Z dawnego Wilna: Szkice obyczajowe i literackie (Vilnius, 1929),

${ }^{76}$ Aleksandravičius, 'Kazimierz Kontrym’, pp. 19-22. 
criticised the closed concept of the nation composed only of nobles. Though they thought the leading figures of the nation would be the nobility, they admitted that noble titles could be given to people of non-noble origins as well, and that a nation was inclusive of the common people. They were interested in Lithuanian mythology and history during the first half of their activities, but ridiculed the script of the Lithuanian language. The Lithuanian nation would have been a Polish-speaking community which would have integrated the ruled classes by improving their living conditions and spreading education in Polish. However, considering the activities of Kontrym and others, the nation could have been a multilingual community under Polish high culture. In any case, it differs from the concept of a class-limited nation of the early modern age, and from that of a linguistically homogeneous nation consisting of all classes, which began to gain popularity in the second half of the 19th century. Therefore, it is possible to say that there has been diversity in the formation of modern nations in Eastern Europe.

\section{Author Details}

Dr Sayaka Kaji is a research fellow of the Japanese Society for the Promotion of Science attached to the School of Humanities, Kwansei Gakuin University, and a lecturer at the Faculty of Letters, Kyoto University, et al. Her scholarly interest is the cultural and intellectual history of the former lands of the Polish-Lithuanian Commonwealth in the 19th century. She is the co-author of The Formation of National Intellectuals and the Development of a University Network in the Regions under the Rule of Russian Empire (Kwansei Gakuin University, 2011).

Address: School of Humanities, Kwansei Gakuin University, 1-155 Uegahara1bancho, Nishinomiya, 662-8501 JAPAN

E-mail: sayakaji@hotmail.com

VILNIAUS INTELIGENTAI IR XIX A. PRADŽIOS ,LIETUVOS‘ SĄVOKA: NENAUDĖLIU DRAUGIJA (TOWARZYSTWO SZUBRAWCÓW) IR VIETINĖ VISUOMENE்

Santrauka

SAYAKA KAJI

Straipsnyje autorè apžvelgia santykius tarp Vilniaus universitetų absolventų, vietinès visuomenès ir liaudies buvusiose Lietuvos Didžiosios Kunigaikštystės žemėse XIX a. pradžioje. Ji pristato vadinamosios Nenaudèlių draugijos veiklą bei jų 1816-1822 m. leistą satyrini žurnalą „Gatvès žinios“ (Wiadomości Brukowe). 
Šio leidinio straipsnių duomenų pagrindu analizuojami du klausimai: kaip draugijos nariai žiūrèjo į tautą bei visuomeninius sluoksnius ir kaip jie vertino Lietuvos istoriją bei jos liaudies kalbas. Draugijos nariu nuomone, visuomenę sudare ne vien tik ponija, bet ir kitų sluoksnių atstovai. „Nenaudèliai“ kritikavo uždarą bajorų tautos sąvoką. Nors jie tikèjo, kad tautai vadovaus bajorai, tačiau pripažino, jog ne-bajorų kilmės žmonės turi teisę issigyti bajorystę, o liaudis taip pat yra tautos dalis. Pradžioje jie domėjosi Lietuvos istorija bei mitologija, tuo pačiu metu laikydami lietuvišką raštą esant juokingą. Lietuvių tauta turejjo būti lenkiakalbe visuomene su geromis gyvenimo sąlygomis ir lenkišku išsilavinimu. Tauta būtų daugiakalbè, o aukštoji kultūra - lenkiška. Ši sąvoka aiškiai skiriasi nuo vienu sluoksniu pagrịstos visuomenès idèjos, kuri gyvavo ankstyvesniais naujaisiais amžiais bei vèlyvesnio XIX a. kalbiškai vieningos tautos modelio. 